\title{
Can open internet access be imposed upon European CATV networks?
}

\author{
Liyang Hou ${ }^{\mathrm{a}, *}$, Peggy Valcke ${ }^{\mathrm{b}}$, David Stevens ${ }^{\mathrm{b}}$ \\ a Koguan Law School, Shanghai Jiao Tong University, Dongchuan Road 800, Shanghai 200240, China \\ ${ }^{\mathrm{b}}$ Faculty of Law, The Interdisciplinary Centre for Law E' ICT (ICRI), Katholieke Universiteit Leuven, Sint-Michielsstraat 6 , \\ B-3000 Leuven, Belgium
}

\section{A R T I C L E I N F O}

Keywords:

Cable television network

Regulation

Broadband

Access regulation

European Union

\begin{abstract}
A B S T R A C T
Broadband over cable television networks has become a growing force on the retail market in the EU. Thus, a debate has always been raised whether cable television networks should also be subject to open internet access obligations as PSTN and fibre. This article aims to share its view from a legal perspective. In order to do so, it conducts a survey of the current regulatory measures on broadband over cable television networks within the $27 \mathrm{EU}$ Member States, and then carries out an in-depth legal analysis on Member States that attempted to regulate broadband over cable television networks. The conclusion is that broadband over cable television networks is currently deregulated, and will probably remain so in the future.
\end{abstract}

(c) 2013 Elsevier Ltd. All rights reserved.

\section{Introduction}

Due to the technological convergence emerging at the end of the last century, broadband services have been able to be delivered over many platforms, prominently PSTN, cable television (CATV) and fibre (Spulber \& Yoo, 2008). In order to promote competition on the broadband market, regulators in general have two options: inter-platform and intra-platform competitions (Picot \& Wernick, 2007). The former enhances competition between different technologies while the latter promotes competition using the same network technology. The intra-platform competition is featured by open-access obligations on the incumbents to open their infrastructures and associated facilities to new comers. These obligations in general contain two types: on the one hand, physical access, including local loop unbundling (LLU) and subloop unbundling, and on the other hand, logical or bitstream access.

The vast majority of countries, including the European Union (EU), have already imposed open internet access obligations on PSTN and/or fibre networks (OECD, 2005). The question nevertheless remains whether CATV networks should also be done the same. From a technical perspective, access to CATV networks by third parties can to some extent be opened, though probably not as efficiently as PSTN or fibre networks. However, the question whether CATV operators can be obliged to provide open internet access is not only technical but also legal. The debate on the legal feasibility of imposing those obligations upon CATV operators arises basically at the same time when broadband began to be offered via CATV networks. Two opposite practices can be observed: some countries introduced open internet access to CATV, e.g. Canada (Van Gorp \& Middleton, 2010) and South Korea (Wu, 2004); and others preferred to leave CATV networks unregulated. In the EU, alongside with the rapid development of broadband over PSTN or fibre since 1990s, broadband over CATV has also

\footnotetext{
* Corresponding author. Tel.: +86 21342044 52; fax: +86 2134205612 .

E-mail addresses: liyang.hou@sjtu.edu.cn (L. Hou), peggy.valcke@law.kuleuven.be (P. Valcke), david.stevens@law.kuleuven.be (D. Stevens).
} 
become a growing force for the provision of broadband services, and in total accounts for $24.7 \%$ of all the broadband offerings including DSL (digital subscriber line), fibre, mobile, satellite and so on (EC, 2010a). In view of the increasing importance of broadband over CATV, the EU also experiences the discussion whether CATV networks should also be subject to ex-ante regulation, in particular open internet access obligations, in the same way as PSTN or fibre.

This article aims to answer this question from a legal perspective based on an empirical approach by examining the regulatory environment within the EU by April 2013. The second part of this article offers a descriptive introduction to the special features of the EU legal context of broadband regulation in order to lay the background for the following analyses. Part 3 offers an overview of the competition situation of broadband over CATV at the retail level. Afterwards, the subsequent two parts surveys the imposition or not of open internet access to CATV networks, respectively on the market for wholesale network infrastructure access (Part 4) and the market for wholesale broadband access (Part 5) within the 27 EU Member States. There, particular focus is placed on some Member States attempting to regulate CATV networks, and an in-depth thinking is also provided on the underlying reasons. After such a study, the last part concludes that CATV networks are still immune to the EU regulatory framework and will probably remain so in the future.

\section{Legal context}

Broadband regulation falls into the scope of the EU telecommunications regulation which must be respected by Member States. In order to examine how broadband over CATV is regulated at national level, it is necessary to have some basic legal knowledge about the EU telecommunications regulatory framework. The following paragraphs first provide a brief introduction to the principles and methodologies that are used to impose open access obligations, and then assess in general how the regulation of CATV can fit into this mechanism.

The current EU telecommunications regulatory framework was pushed forward by technological convergence starting in 1990s. Technological convergence made it difficult to regulate the telecommunications sector based on platforms or technologies. In order to adapt to this phenomenon the EU adopted a technologically neutral approach for telecommunications regulation in 2002 and had it amended in 2009. This approach is the so-called significant-market-power (SMP) regime, of which the core elements are incorporated in the articles 14-16 of the Framework Directive (EU, 2009a).

According to this regime, EU Member States, in order to regulate a telecommunications undertaking, must conduct an analysis on three cumulative conditions: (i) to define a relevant market, (ii) to assess whether there is an undertaking individually, or collectively with others, having SMP, and (iii) to impose regulatory obligations only upon the undertaking(s) with SMP. This is the so-called three-step analysis. Only telecommunications undertakings whose products are included into defined relevant markets are then analysed by NRAs to see whether they may be designated to have SMP; moreover, only undertakings designated to have SMP can be subject to regulatory obligations. It is one of the regulatory obligations imposed upon SMP undertaking to open their networks to third parties. Undertakings whose products are excluded from the delineation of a relevant market and those whose products are included in a relevant market and that are nevertheless not found to have SMP should otherwise not be regulated.

Consequently, the question whether a CATV network should be obliged to open to third parties can be boiled down to two sub-questions: (i) whether a CATV network can be included in a recommended relevant market; and if so, then (ii) whether this CATV operator has SMP on that relevant market. The first question is more important than the second one as an exclusion from market definition is nothing more than a clearance that operators providing the excluded telecommunications services are not candidates of SMP operators (the second step) and hence will be not regulated (the third step). This explains why CATV operators focused so much on market definition when arguing that they should not be regulated (Cable Europe, 2006).

In order to enhance harmonisation, the EU does not leave the definition of relevant markets to the sole discretion of Member States. The Commission is required to publish a recommendation on relevant markets that are susceptible to ex-ante regulation (the Recommendation) (EC, 2007a). The Recommendation in general summarises the practices under competition law in market definition. Accordingly, telecommunications markets should be defined based on demand-side and supply-side substitution. This is usually performed through a hypothetical monopoly test to examine the reaction of consumers to a small but significant and non-transitory increase in price (SSNIP). This test also implies that market definition and market power assessment are to some extent intertwined (Schwarz, 2007). More specifically, the answer to the hypothetical monopolist test amounts to the answer to the market power assessment itself: if the hypothetical monopolist can profitably raise a SSNIP, it is a monopolist. Due to this feature, national regulatory authorities (NRAs) sometimes mix market definition with market power assessment. This has a profound impact on the practice of market definition, which will be elaborated further in the following parts.

In addition to the synthesis of competition-law practices, the Recommendation also entails some sector-specific elements. One of the most important is that it defines wholesale markets based on the demand derived from the related retail markets. Regarding the provision of broadband, the Recommendation, in order to allow alternative operators without own infrastructures to provide retail broadband services, defines two wholesale products: physical network access (i.e. local loop unbundling and sub-loop unbundling), and non-physical or virtual network access (including bitstream access). The former is referred to as wholesale network infrastructure access (Market 4), while the latter as wholesale broadband access (Market 5) (EC, 2007a). 
The open-Internet-access obligation, or access obligation under Article 12 of the Access Directive (EU, 2009b), is normally imposed only on Market 4 and Market $5 .{ }^{1}$ Consequently, if a regulator wants to impose access obligations on CATV networks, it has to first examine whether CATV should be considered part of Market 4 and/or Market 5. However, two problems come out in relation to the analysis of such a market definition. First, CATV usually does not pose direct constraints on PSTN at the wholesale level. This lack of direct constraints is often due to the fact of high switching costs that DSL-based wholesale customers have to bear when migrating to CATV-based products, and vice versa. Therefore, it is likely that neither of them will switch to CATV operators in case of a SSNIP. Secondly, CATV may exercise indirect constraints from retail markets. This will be the case if PSTN operators initiate a SSNIP on the wholesale markets, a large number of broadband end-users switch to retail broadband over CATV so as to make the wholesale price increase unprofitable. In this case, PSTN wholesale operators cannot behave independently of CATV operators even though the latter exert no direct constraints. However, the Recommendation asserts that "indirect pricing constraint, where it is found to exist, should be taken into account when assessing if the incumbent DSL operator has SMP on the relevant market" (EC, 2007b, p. 35), hence, not in the stage of defining the relevant market. ${ }^{2}$ This statement seems to imply that CATV networks are not supposed to be subject to ex-ante regulation as they are not included in Market 4 and Market 5. This view nevertheless has not been able to reach consensus among all the Member States. As discussed in the following, the treatment of indirect constraints underlies the tension between the Commission and some Member States regarding regulating broadband over CATV.

\section{CATV in the retail broadband market}

Open internet obligation falls into the so-called wholesale regulations, the purpose of which is to promote competition at the retail level. Therefore, when imposing such an obligation, Member States must first take a look at the retail market. This article follows the same logic by examining retail broadband over CATV first.

From a legal perspective, the investigation of retail markets has two purposes. First, wholesale markets (where open internet obligation is imposed) are defined based on the demand- and supply-side substitution derived from the retail level. Therefore, it is always the first step for Member States to delineate the boundaries of retail markets within the SMP regime, and then to go upwards to investigate the related wholesale markets. Secondly, as indicated in Part 2, the analysis of indirect constraints is the key in deciding whether CATV can be subject to open internet access obligation. Inderst and Valletti (2007a) indicate that indirect constraints are particularly effective if the retail market is highly competitive, and they become more important than direct constraints if the upstream market is relatively less competitive compared to the retail market. This is exactly the situation in broadband markets in the EU where the retail markets are more or less competitive while the wholesale markets are not. Moreover, although retail market shares should not be a decisive factor, it is informative on the effectiveness of indirect constraints. Therefore, Table 1 is drawn to display the market shares of broadband based on different technologies on the retail market in all the 27 Member States.

The first observation from Table 1 is that CATV broadband operators in most EU Member States have not been able to make a significant presence on the retail market. On the EU scale their influence is in general considerably less than PSTN operators. This can be in particular seen in Greece and Italy where there is no broadband via CATV at all. This also implies that CATV operators should in general not be regulated on the wholesale markets as they hardly enjoy SMP. Against this general situation, it is also observed that in some Member States broadband over CATV has been able to gain large market shares on the retail broadband market. Those Member States comprise Malta, Hungary, Belgium, Portugal and the Netherlands where CATV operators account for over or close to $40 \%$ market shares. Despite such a substantial presence in those Member States, attention should be paid to a fact that in most EU countries CATV networks are on the one hand scattered in terms of geographic coverage and on the other hand are usually owned by a large number of operators (Cable Europe, 2010). In comparison, PSTN networks are always ubiquitous and highly concentrated. This fact in general hinders individual CATV operators from overwhelming PSTN operators, and hence becoming SMP operators. However, the large amount of market shares of CATV operators taking as a whole may possibly challenge the market position of their PSTN counterparts through indirect constraints. In other words, those PSTN incumbents may be then found to have no market power due to the strong presence of CATV operators. Based on such a thought, the next two parts survey how the retail competition has been reflected at the wholesale level.

\section{CATV regulation in Market 4}

As discussed in Part 1, open internet access obligations are of two types: physical access and bitstream access. According to the EU regulation, physical access can only be imposed on Market 4. It is thus surveyed in the following whether Member States have already imposed physical access obligations on CATV operators, and if so why.

Market 4 is defined by the EU to comprise physical access products to local loops. In order to impose an obligation of local loop unbundling, NRAs must include CATV networks into Market 4 based on the demand-side and supply-side

\footnotetext{
${ }^{1}$ The Recommendation (EC, 2007a) provides Member States with a possibility to define relevant markets beyond what it recommends. In other words, an open-Internet-access obligation may also be imposed on markets other than Market 4 and/or 5. However, the standard of proof to define new markets is very high. As a result, Member States usually follow the Commission's recommended markets.

${ }^{2}$ Nevertheless, it still remains a debate in economics how to deal with indirect constraints (Inderst \& Valletti, 2007b).
} 
Table 1

Country report on the market shares of retail broadband based on different technologies (as of January 2010). Source: adapted from EC (2010a).

\begin{tabular}{|c|c|c|c|}
\hline MS & DSL (\%) & Cable (\%) & Other technologies (\%) \\
\hline AT & 68 & 30 & 2 \\
\hline $\mathrm{BE}$ & 57 & 42 & 1 \\
\hline BG & 31 & 13 & 56 \\
\hline $\mathrm{CY}$ & 94 & 6 & 0 \\
\hline$C Z$ & 39 & 22 & 39 \\
\hline $\mathrm{DE}$ & 90 & 9 & 1 \\
\hline DK & 60 & 27 & 13 \\
\hline $\mathrm{EE}$ & 42 & 21 & 37 \\
\hline EL & 100 & 0 & 0 \\
\hline ES & 80 & 19 & 1 \\
\hline FI & 76 & 14 & 10 \\
\hline FR & 95 & 5 & 0 \\
\hline $\mathrm{HU}$ & 44 & 45 & 11 \\
\hline IE & 72 & 10 & 18 \\
\hline IT & 97 & 0 & 4 \\
\hline LV & 49 & 8 & 43 \\
\hline LT & 36 & 9 & 55 \\
\hline LU & 83 & 16 & 1 \\
\hline MT & 48 & 49 & 3 \\
\hline NL & 62 & 36 & 2 \\
\hline PL & 56 & 27 & 17 \\
\hline PT & 59 & 38 & 3 \\
\hline RO & 28 & 17 & 55 \\
\hline SE & 59 & 20 & 21 \\
\hline SI & 62 & 22 & 16 \\
\hline SK & 46 & 10 & 44 \\
\hline UK & 79 & 21 & 0 \\
\hline
\end{tabular}

substitution (i.e. direct constraints). The Recommendation maintains that "the unbundling of cable networks at this stage does not appear technologically possible, or economically viable, so that an equivalent service to local loop unbundling cannot be provided over cable networks" (EC, 2007b, p. 31). This has been confirmed by the European Regulators Group (ERG, currently the Body of European Regulators for Electronic Communications, or BEREC). The ERG (2005) suggests a technical possibility that an alternative operator may co-locate equipment of cable modem termination system at cable operators' headend and interface to the Hybrid Fibre-Coaxial network, which has the same effect of local loop unbundling. However, even the ERG acknowledges that this could only work with a small number of third parties due to spectrum limitation. Since CATV networks cannot be unbundled at the same degree as PSTN, they cannot exert sufficient direct constraints on PSTN networks. Furthermore, the Recommendation makes it clear that even if CATV can impose indirect constraints from the retail level, those constraints should not be taken into account at the stage of market definition, but in the phase of SMP assessment. Consequently, the conclusion of the Recommendation is that broadband over CATV should not be included into Market 4, provided the unbundling of CATV networks remains technically or economically unviable.

Table 2 contains the information about the latest notifications of every EU Member State with regard to Market 4. This table clearly shows that almost all Member States followed the approach within the Recommendation and excluded CATV from Market 4. However, it is also observed that there are two maverick Member States, Portugal and the UK, which deviated from this approach and included CATV on Market 4. In the following, this article attempts to answer two questions concerning the two notifications: (i) how they reached such a conclusion and (ii) why the Commission approved their proposals.

Neither ANACOM (the Portuguese regulator) nor Ofcom (the UK regulator) submitted that CATV could exert direct constraints on PSTN. Their analyses of including broadband over CATV in Market 4 focused on indirect constraints. Both of them alleged that the price of wholesale input occupied a significant part of the retail price, i.e. 50\% in the Portuguese notification and $65-75 \%$ in the UK notification (EC, 2010c). Thus, in case of $10 \%$ price increase at the wholesale level there should be more than $5 \%$ price increase at the retail level. As a consequence, end users would switch to CATV-based broadband to an extent that would make the wholesale price increase unprofitable. CATV was accordingly considered on the same relevant market as PSTN.

However, the Commission disagreed with this analysis in both of the notifications. In particular, it held that it would not be possible for the price increase to entirely pass on to the end users of retail broadband access products. This was due to the fact that an LLU price increase could also affect other retail products, such as voice telephony and IPTV. Moreover, it was also doubtful that competitors would not be able to partly absorb a $10 \%$ price increase in their margins. Nevertheless, the Commission did not disapprove the two notifications. The main reason was that both ANACOM and Ofcom still proposed to designate the PSTN incumbents as SMP operators. Hence, the Commission accepted the two notification as an exclusion of cable from the definition of Market 4 would not lead to a different conclusion. This corresponds to the generally recognised 
Table 2

Country report for Market 4

Source: adapted from EC (2013)

\begin{tabular}{|c|c|c|c|c|c|c|c|c|}
\hline MS & $\begin{array}{l}\text { Date of } \\
\text { notifications }\end{array}$ & $\begin{array}{l}\text { Is CATV } \\
\text { included? }\end{array}$ & $\begin{array}{l}\text { Other } \\
\text { technologies }\end{array}$ & $\begin{array}{l}\text { Direct } \\
\text { constraints }\end{array}$ & $\begin{array}{l}\text { Indirect } \\
\text { constraints }\end{array}$ & $\begin{array}{l}\text { Wholesale CATA } \\
\text { offer }\end{array}$ & SMP operators & Access remedies \\
\hline AT & 17.06.2010 & No & Fibre & No & No & No & PSTN+fibre & PSTN+fibre \\
\hline $\mathrm{BE}$ & 20.05 .2011 & No & No & No & No & No & PSTN & PSTN \\
\hline BG & 27.01.2011 & No & Fibre & No & No & No & PSTN+fibre & PSTN+fibre \\
\hline $\mathrm{CY}$ & 14.12 .2012 & No & Fibre & No & No & No & PSTN+fibre & PSTN+fibre \\
\hline $\mathrm{CZ}$ & 03.05.2010 & No & Fibre & No & No & No & PSTN+fibre & PSTN+fibre \\
\hline $\mathrm{DE}$ & 20.09.2010 & No & Fibre & No & No & No & PSTN+fibre & PSTN+fibre \\
\hline DK & 09.07.2012 & No & Fibre & No & No & No & PSTN+fibre & PSTN+fibre \\
\hline $\mathrm{EE}$ & 30.07.2009 & No & Fibre & No & No & No & PSTN+fibre & PSTN+fibre \\
\hline EL & 01.07.2011 & No & No & No & No & No & PSTN+fibre & PSTN+fibre \\
\hline ES & 13.11.2008 & No & No & No & No & No & PSTN & PSTN \\
\hline FI & 18.10.2012 & No & Fibre & No & No & No & PSTN+fibre & PSTN+fibre \\
\hline FR & 26.05 .2011 & No & Fibre & No & No & No & PSTN+fibre & PSTN+fibre \\
\hline HU & 01.04.2011 & No & Fibre & No & No & No & PSTN+fibre & PSTN+fibre \\
\hline IE & 17.12.2012 & No & Fibre & No & No & No & PSTN+fibre & PSTN+fibre \\
\hline IT & 27.06.2011 & No & Fibre+wireless & No & No & No & PSTN+fibre & PSTN+fibre \\
\hline LT & 06.05 .2011 & No & $\begin{array}{l}\text { Fibre+twisted } \\
\text { pair }\end{array}$ & No & No & No & $\begin{array}{l}\text { PSTN+fibre } \\
\text { +twisted pair }\end{array}$ & $\begin{array}{l}\text { PSTN+fibre } \\
\text { +twisted pair }\end{array}$ \\
\hline LU & 27.10 .2006 & No & No & No & No & No & PSTN & PSTN \\
\hline LV & 12.11.2009 & No & Fibre & No & No & No & PSTN & PSTN \\
\hline MT & 15.11.2012 & No & Fibre & No & No & No & PSTN+fibre & PSTN+fibre \\
\hline NL & 21.12.2012 & No & Fibre & No & No & No & PSTN+fibre & PSTN+fibre \\
\hline PL & 29.10 .2010 & No & Fibre & No & No & No & PSTN+fibre & PSTN+fibre \\
\hline PT & 05.01.2009 & Yes & Fibre & No & Yes & No & PSTN+fibre & PSTN+fibre \\
\hline RO & 06.08 .2010 & No & Fibre & No & No & No & PSTN+fibre & PSTN+fibre \\
\hline SE & 19.04.2010 & No & Fibre & No & No & No & PSTN+fibre & PSTN+fibre \\
\hline SI & 22.12 .2010 & No & Fibre & No & No & No & PSTN+fibre & PSTN+fibre \\
\hline SK & 19.04.2012 & No & Fibre & No & No & No & PSTN+fibre & PSTN+fibre \\
\hline UK & 01.06.2010 & Yes & Fibre & No & Yes & No & PSTN+fibre & PSTN+fibre \\
\hline
\end{tabular}

importance of market definition that it is not an end in itself, but a tool to identify market power (Jones \& Sufrin, 2011), and also echoes the argument made earlier in this article that market definition is not an individual analysis, but intertwine with the subsequent analysis of market power. Since the deviation did not affect the designation of SMP operators, the Commission found no need to disapprove those two NRAs' proposals. However, it should be noted that if NRAs include cable into the delineation of Market 4 and in the end find that some cable operator actually has SMP and should be regulated, the Commission may veto their proposals according to Article 7 of the Framework Directive.

\section{CATV regulation in Market 5}

The second type of open internet access (i.e. logical or bitstream access) is affiliated to Market 5 . In the following, this part is dedicated to examining the views of the Commission and Member States on imposing bitstream access on CATV operators. It is observed that while most Member States sided with the Commission some ones began to challenge the latter. In view of such a conflict, a country-by-country study is carried out in order to identify the underlying reasons for such a conflict.

Market 5 is defined as including bitstream access that permits the transmission of broadband data in both directions, as well as other wholesale access provided over other infrastructures, if and when they offer facilities equivalent to bitstream access. Since broadband over CATV can permit the transmission of broadband data in both directions, it is potentially part of Market 5 from a technical standpoint. The ERG (2005) also recognised the technical possibilities to provide wholesale broadband access over CATV through Layer 2 solutions and Layer 3 solutions. In addition, this article also notices that wholesale broadband access over CATV is currently commercialised in five Member States, i.e. Austria, France, Hungary, Malta and the Netherlands.

Despite such technical and commercial possibilities and realities, the Commission seems not to support the idea of including CATV into Market 5. It maintains that the migration from DSL-based access to CATV-based access would give rise to substantial switching costs so that switching is unlikely to occur in reaction to a SSNIP. Furthermore, since the geographical coverage of CATV networks is in general limited, alternative operators need to negotiate with multiple CATV operators in order to offer national-wide broadband provision. Therefore, the Commission expresses concerns on the likeliness that CATV can impose direct competition against PSTN (EC, 2008a). Moreover, as regards the indirect constraints that CATV operators may exercise on the providers of DSL-based wholesale broadband access, the Commission, in accordance with the Recommendation, underlines that "such indirect pricing constraint, where it is found to exist, should be taken into account when assessing if the incumbent DSL operator has SMP on the relevant market" (EC, 2007b, p. 35). It has 
Table 3

Countries excluding CATV from Market 5.

Source: adapted from EC (2013).

\begin{tabular}{|c|c|c|c|c|c|c|c|c|}
\hline MS & $\begin{array}{l}\text { Date of } \\
\text { notifications }\end{array}$ & $\begin{array}{l}\text { Is CATV } \\
\text { included? }\end{array}$ & $\begin{array}{l}\text { Other } \\
\text { technologies }\end{array}$ & $\begin{array}{l}\text { Direct } \\
\text { constraints }\end{array}$ & $\begin{array}{l}\text { Indirect } \\
\text { constraints }\end{array}$ & $\begin{array}{l}\text { Wholesale CATV } \\
\text { offer }\end{array}$ & $\begin{array}{l}\text { SMP } \\
\text { operators }\end{array}$ & $\begin{array}{l}\text { Access } \\
\text { remedies }\end{array}$ \\
\hline $\mathrm{BE}$ & 20.05 .2011 & No & No & No & No & No & PSTN+fibre & PSTN+fibre \\
\hline BG & 27.01.2011 & No & Fibre & No & No & No & PSTN+fibre & PSTN+fibre \\
\hline $\mathrm{CY}$ & 14.12 .2012 & No & Fibre & No & No & No & PSTN+fibre & PSTN+fibre \\
\hline $\mathrm{CZ}$ & 10.08 .2012 & Yes (veto) & Fibre & No & Yes & No & PSTN+fibre & PSTN+fibre \\
\hline EL & 01.07.2011 & No & No & No & No & No & PSTN+fibre & PSTN+fibre \\
\hline ES & 26.12 .2008 & No & No & No & No & No & PSTN+fibre & PSTN+fibre \\
\hline FR & 26.05 .2011 & No & Fibre & No & No & Yes & PSTN+fibre & PSTN+fibre \\
\hline IE & 17.12 .2012 & No & Fibre & No & No & No & PSTN+fibre & PSTN+fibre \\
\hline IT & 14.04.2009 & No & Fibre+wireless & No & No & No & PSTN+fibre & PSTN+fibre \\
\hline LT & 31.10 .2012 & No & No & No & No & No & PSTN+fibre & PSTN+fibre \\
\hline LU & 30.10 .2006 & No & No & No & No & No & PSTN & PSTN \\
\hline PL & 08.02 .2013 & No & Fibre & No & No & No & PSTN+fibre & PSTN+fibre \\
\hline RO & 06.08 .2010 & No & Fibre & No & No & No & Competitive & No \\
\hline SE & 19.04.2010 & No & Fibre & No & No & No & PSTN+fibre & PSTN+fibre \\
\hline SI & 22.12 .2010 & No & Fibre & No & No & No & PSTN+fibre & PSTN+fibre \\
\hline SK & 23.07.2012 & No & Fibre & No & No & No & PSTN+fibre & PSTN+fibre \\
\hline
\end{tabular}

been observed, as shown in Table 3, that fifteen countries concurred with the Commission's statement, and excluded CATV networks from Market 5. The direct consequence was CATV operators are not considered undertakings able to have SMP and thus should be subject to no regulation.

However, the Commission does not close the door completely. While pointing out that CATV operators in principle cannot exert direct constraints on PSTN operators, the Commission does suggest that it may be not always the case. For such a purpose, it provides some guidance for Member States to evaluate whether CATV can be considered as part of Market 5 . The Commission states that when a Member State considers that CATV operators can exert direct constraints, it should give due consideration to the technical, practical and economic feasibility for CATV operators to offer facilities equivalent to bitstream access (EC, 2009). As pointed out in the previous paragraph, there is no absolute technical infeasibility to realise wholesale broadband access over CATV networks. The Commission's focus was accordingly on the practical and economic feasibility. More specifically, it expects Member States to provide evidence on the capacity of CATV wholesale broadband access to offer comparable critical product characteristics as those provided by DSL, notably in terms of service management. Furthermore, Member States should also assess whether product differences may render it difficult for an ISP to switch from DSL to a CATV wholesale broadband offer, independent of the possible technical substitutability. This can be done, for example, by providing evidence that incentives for a wholesale migration are not significantly limited by necessary modem replacements and reconfigurations (EC, 2010d). In addition, when a Member State intends to rely on the effect of indirect substitution through a SSNIP test, the Commission demands a hypothetical monopolist test. In particular, Member States must demonstrate that

(i) "Internet service providers would be forced to pass a hypothetical wholesale price increase on to their consumers at the retail level based on the wholesale/retail price ratio without being able to absorb it;

(ii) there would be sufficient demand substitution at the retail level to retail services based on indirect constraints such as to render the wholesale price increase unprofitable; and

(iii) the customers of the ISPs would not switch to a significant extent to the retail arm of the integrated hypothetical monopolist, in particular if the latter does not raise its own retail prices" (EC, 2008a, p. 7).

Nevertheless, the standard of proof set up by the Commission is quite high. As a matter of fact, there are in total twelve Member States that decided to deviate from the Recommendation and included CATV in Market 5. Those Member States comprises Austria, Czech, Denmark, Estonia, Finland, Germany, Hungary, Latvia, Malta, Netherlands, Portugal, and the UK. The high burden of proof can be observed from the fact that none of those Member States actually convinced the Commission of their conclusions. It is expected that the Commission vetoed the proposal of the Czech NRA as it cannot prove both direct constraints and indirect constraints between CATV and DSL (EC, 2012). However, it is of surprise that the Commission approved all the other proposals. In view of such a contradiction, the subsequent paragraphs attempts to discover the underlying reasons in those eleven notifications.

In order to do so, this article examines first whether the inclusion of CATV into Market 5 would have changed the final regulatory outcome, i.e. either the designation of SMP operators or the imposition of regulatory remedies. As discussed in the previous part, the inclusion of CATV networks into Market 4 by Portugal and the UK did not affect the assessment of SMP at all, and hence the Commission, though disagreeing with their analyses, still approved the two's proposals. If it is still the case here, an easy conclusion can then be drawn that CATV networks so far still cannot exert direct constraints on PSTN networks and thus should be not regulated. 
However, the situation regarding Market 5 goes differently from that regarding Market 4. Through examining the question raised in the above, it is found that in seven Member States the inclusion or exclusion of CATV network did not affect the final regulatory outcome while for the other four Member States it actually could. Based on such a finding, those eleven Member States deviating from the Commission's recommendation are divided into two groups. The first group includes seven Member States, i.e. Austria, Estonia, Finland, Germany, Hungary, Latvia, and the Netherlands, as shown in Table 4. The second group comprises four Member States, namely Denmark, Malta, Portugal and the UK, as in Table 5.

Within the first group of countries where CATV network were proposed to be included into the definition of Market 5, all those countries found that the presence of broadband over CATV in those countries was nevertheless unable to sufficiently restrain the market power of PSTN incumbents. Therefore, when assessing who has SMP after the market definition stage, all those countries made the same conclusion that it was still those PSTN incumbents that should be designated as SMP operators, thus being subject to regulatory obligations. Furthermore, CATV's insubstantial market position suggests that an exclusion from the definition of Market 5 is nothing more than letting PSTN incumbents controlling, if not monopolising, Market 5. Hence in either case it is still PSTN incumbents that should be regulated in the end. As the regulatory outcome remained the same, the Commission found no need to veto those NRAs' notifications. This is similar to its practice with regard to the notifications of Portugal and the UK within the previous part of this article. Consequently, the Commission still considered that CATV networks were not substitutes for PSTN networks for the purpose of wholesale broadband access.

Subsequently, the analysis moves to the more controversial second group of countries. Unlike the first group, the exclusion of broadband over CATV networks could have led to different regulatory decisions in the second groups, by either affecting the designation of SMP operators or the scope of regulatory remedies. In other words, if CATV networks, as the Commission states, be excluded from Market 5, a different regulatory outcome would have been reached, such as CATV operators that were regulated would have been deregulated, or PSTN incumbents that were deregulated would have been regulated. Thus, two questions are raised for a further investigation: (i) how those countries established direct constraints between CATV networks and PSTN networks; and (ii) if they did not, why the Commission did not veto their notifications. Since the national circumstances varied in those four countries, the following examination will be carried out on a percountry basis.

The unique feature in the Danish notification (EC, 2008b) is that it is the only case so far where a Member State has proposed to impose open access obligations upon a CATV operator. Apparently, an exclusion of CATV from Market 5 would mean that the CATV network should have not been regulated, thus making this case distinct from the first group of cases. In Denmark, the broadband market presents a market structure that differs from other Member States in that the incumbent owns both a PSTN network and a CATV network. Before the notification, the Danish incumbent was only subject to access obligations on its PSTN network. However, a market failure was gradually observed as the incumbent began to slow down the upgrade on its PSTN network, and instead made substantial investment on its CATV network that was unregulated. The Danish regulator, NITA, was concerned that DSL-based alternative operators would be left behind by such a circumventing strategy. This was the underlying reason for NITA to include CATV on Market 5. The Commission, while affirming that it was

Table 4

Countries including CATV in Market 5 (Group 1).

Source: adapted from EC (2013).

\begin{tabular}{|c|c|c|c|c|c|c|c|c|}
\hline MS & $\begin{array}{l}\text { Date of } \\
\text { notifications }\end{array}$ & $\begin{array}{l}\text { Is CATV } \\
\text { included? }\end{array}$ & $\begin{array}{l}\text { Other } \\
\text { technologies }\end{array}$ & $\begin{array}{l}\text { Direct } \\
\text { constraint }\end{array}$ & $\begin{array}{l}\text { Indirect } \\
\text { constraint }\end{array}$ & $\begin{array}{l}\text { Wholesale CATV } \\
\text { offer }\end{array}$ & $\begin{array}{l}\text { SMP } \\
\text { operators }\end{array}$ & $\begin{array}{l}\text { Access } \\
\text { remedies }\end{array}$ \\
\hline AT & 25.10 .2010 & Yes & Fibre & No & Yes & Yes & PSTN+fibre & PSTN+fibre \\
\hline DE & 06.09.2010 & Yes & Fibre & Yes & No & No & PSTN+fibre & PSTN+fibre \\
\hline $\mathrm{EE}$ & 30.07.2009 & Yes & Fibre & Yes & No & No & PSTN+fibre & PSTN+fibre \\
\hline FI & 18.10.2012 & Yes & Fibre & No & Yes & No & PSTN+fibre & PSTN+fibre \\
\hline $\mathrm{HU}$ & 01.04.2011 & Yes & Fibre & Yes & Yes & Yes & PSTN+fibre & PSTN+fibre \\
\hline LV & 08.03.2010 & Yes & Fibre+wireless & No & Yes & No & PSTN & PSTN \\
\hline NL & 21.12.2012 & Yes & Fibre & No & Yes & Yes & PSTN+fibre & PSTN+fibre \\
\hline
\end{tabular}

Table 5

Countries including CATV in Market 5 (Group 2).

Source: adapted from EC (2013).

\begin{tabular}{|c|c|c|c|c|c|c|c|c|}
\hline MS & $\begin{array}{l}\text { Date of } \\
\text { notifications }\end{array}$ & $\begin{array}{l}\text { Is CATV } \\
\text { included? }\end{array}$ & $\begin{array}{l}\text { Other alternative } \\
\text { technologies }\end{array}$ & $\begin{array}{l}\text { Direct } \\
\text { constraints }\end{array}$ & $\begin{array}{l}\text { Indirect } \\
\text { constraints }\end{array}$ & $\begin{array}{l}\text { Wholesale CATV } \\
\text { offer }\end{array}$ & SMP operators & $\begin{array}{l}\text { Access } \\
\text { remedies }\end{array}$ \\
\hline DK & 09.07.2012 & Yes & Fibre+wireless & Yes & No & No & $\begin{array}{l}\text { PSTN+fibre } \\
+ \text { CATV }\end{array}$ & $\begin{array}{l}\text { PSTN+fibre } \\
+ \text { CATV }\end{array}$ \\
\hline MT & 15.11.2012 & Yes & Fibre+wireless & Yes & No & Yes & Competitive & No \\
\hline PT & 05.01.2009 & Yes & Fibre & No & Yes & No & PSTN+fibre & PSTN+fibre \\
\hline UK & 01.10 .2010 & Yes & Fibre & No & Yes & No & PSTN+fibre & PSTN+fibre \\
\hline
\end{tabular}


not convinced by NITA's reasoning to include CATV based on direct and indirect constraints, acknowledged that it was justified to extend the remedies to cover also the incumbent's CATV network and to require it to comply with all reasonable requests for access. In exceptional circumstances, the SMP regime also allows Member States to impose proportionate and justified obligations in an area outside but closely related to the relevant market under review. Therefore, the question of exact market boundaries could be left open. Consequently, it may be argued that the Commission in this case still maintained that CATV networks could not exert direct constraints on PSTN networks. Its reason to acknowledge the appropriateness of the notification is that the incumbent circumvented the regulation over PSTN based on its ownership on the largest CATV network in Denmark.

In the Maltese notification (EC, 2008c) the direct consequence of including CATV was that no operators were designated as having SMP, and the whole market was left unregulated. The exclusion of the CATV network would turn the PSTN operator into a near monopoly. The special feature of the broadband market in Malta is that it has the best inter-platform competition among all the EU Member States. There are three networks (PSTN, CATV and WiMax) all with fully national coverage, which probably benefits from the fact that Malta is one of the most densely populated countries in the world. In particular, as indicated in Table 1, the PSTN operator and the CATV operator have similar market shares at the retail level. In the decision, the Commission disagreed with the Maltese NRA's conclusion that wholesale broadband access provided over CATV and DSL could form part of the same market. However, it still approved this proposal. The Commission did not explain in its decision why it allowed such a proposal. Nevertheless, a possible explanation may be that even if the CATV network would be excluded from the phase of market definition, its market power must still be taken into account in the second phase, i.e. assessing whether the PSTN incumbent could have SMP. Despite the fact that it will not be considered as candidates of SMP operators, the CATV operator with a network covering the whole Malta may be considered as a constraining force that makes the PSTN incumbent unable to act independently of its competitors, customers or ultimately consumers, and thus no SMP (Hou, 2008). Since the outcome on SMP designation would possibly remain the same, the Commission approved this notification. Consequently, the Commission here was still of the opinion that CATV networks cannot be included into Market 5 .

It is interesting to compare the Maltese notification with the Hungarian notification categorised in the first group (EC, 2011a). The broadband sectors of the two Member States are very similar. First, both of them have a relatively similar retail market structure between PSTN and CATV. Secondly, broadband over CATV in both countries are the strongest in the EU, with Malta sitting on the top and Hungary following. Last but not least, both Member States decided to include CATV in Market 5 in their regulatory decisions. However, it turns out that Malta concluded that its Market 5 was competitive whereas Hungary designated the three PSTN incumbents as SMP operators. Despite the similarities, there is indeed one major difference between the two countries. In Malta, the CATV network, similar to the PSTN network, belongs to one operator and has footprints all over the country. By contrast, both the CATV network coverage and ownership in Hungary are "scattered or fragmented" (Bánhidi \& Pápai, 2010, p. 13). They are disadvantaged to some extent by the ubiquitous networks of their PSTN counterparts. Furthermore, alternative operators, when switching to CATV networks, would be handicapped by the fact that they must reach access agreements with a large number of CATV operators. Therefore, those CATV operators, though making a significant influence at the retail level, are not considered to constrain the PSTN incumbent due to their small size individually. However, this article is of the opinion that if those CATV networks are not considered to exert sufficient competition on the PSTN operators, they should not be considered as effective substitutes at the stage of market definition. Consequently, the Hungarian NRA should have not included them into Market 5. However, since the regulatory outcome would remain the same, the Commission in the end still approved the Hungarian notification.

If the overlap between market definition and SMP assessment is not unambiguous in other cases, it cannot be clearer within the Portuguese notification (EC, 2008d) and the UK notification (EC, 2010c). Both Member States took CATV into account when defining geographic relevant markets. More specifically, the two Member States separated CATV-strong regions from others, and hence defined two sub-national geographic markets in their territories, i.e. regions with strong presence of broadband over CATV and regions with weak or no presence of broadband over CATV. The inclusion of CATV thus made a difference in that Market 5 would otherwise have been defined as a national market. Most importantly, the taking into account of CATV networks resulted into the deregulation of the PSTN incumbent in CATV-strong regions. To some extent, these two notifications bear similar results to the Maltese notification with the only difference that in the former deregulation took place at sub-national level while in the latter deregulation was made on a national scale. However, the definition of sub-national geographic markets can be considered as a preliminary analysis of SMP (Hou, 2010). Within the two notifications, the Commission agreed with neither of the two NRAs' justifications for the inclusion of CATV. However, since both Member States claimed that they took CATV into account only when its presence was capable of exercising a sufficient competitive constraint, they accordingly already kept the assessment of market power into mind when defining sub-national markets. Although such competitive constraints were not recognised by the Commission as a sufficient justification to include CATV in Market 5, they should be definitely one of the factors to assess SMP. Furthermore, even if an operator has been designated to have SMP on a national scale, geographical imbalance of market power may be relied upon by NRAs to impose different remedies across regions (EC, 2008e). Thus, even if CATV networks had been excluded from Market 5, it would still be possible that the two NRAs may impose different remedies in CATV-strong regions and CATV-weak regions. Consequently, although the designation of the SMP operator may be different in term of the scope of the geographic market (the exclusion of CATV could lead to a national market), the imposition of regulatory obligations would probably remain the same. The Commission therefore accepted these notifications. Here again, the Commission did 
not accept the direct substitution between CATV networks and PSTN networks either in Portugal or in the UK. Therefore, it was still of the view that CATV networks should not be included into the definition of Market 5 .

In conclusion, it is found that although many Member State included CATV into Market 5 the Commission's opinion that CATV should not be regulated still remains unaffected. In all the cases, the inclusion of CATV was only a result of carrying out market power assessment at the stage of market definition. In view of the intertwined nature of the two analyses, those Member States' practice was not really a deviation from the Recommendation. Moreover, the imposition of open access obligation to CATV network in Denmark may be considered as an exceptional circumstance with no general implication.

\section{Conclusions}

The answer to the question whether CATV can be subject to open internet access is not only a technical one but also a legal one. The EU telecommunications regulatory framework implements a technological neutral principle, and does not provide a clear answer. The analyses in the above aim to shed some light on the answer from a legal perspective based on the examination of the current regulatory environment in the EU 27 Member States.

From a legal perspective, the open-Internet-access obligation must be imposed according to the SMP regime. Consequently, the answer to the question whether CATV operators can be obliged to open their networks is boiled down to a question whether CATV networks can be included into Market 4 and/or Market 5 according to direct and indirect substitution. The Commission is of the view that (i) broadband over CATV cannot exert direct constraints on PSTN networks on these two wholesale markets; (ii) indirect constraints, even if existing, must be analysed under the stage of SMP assessment, rather than market definition. Since in either cases CATV operators cannot be considered as candidates for SMP operators, it seems fair to conclude that broadband over CATV should in principle not be regulated according to the EU telecommunications regulatory framework.

However, the survey of national implementation suggests that some Member States deviated from the Commission's approach and included CATV into Market 4 and Market 5; and the Commission nevertheless still approved their notifications based on the finding that the exclusion of CATV networks would not result into different regulatory outcomes. The Commission should not be blamed for its end-justifying-means practice. It has been pointed out at the beginning of this article that the approach for market definition, i.e. the hypothetical monopoly test, makes market definition and market power assessment to some extent mixed up. Therefore, those Member States did not commit an absolute error by already taking into account indirect constraints at the stage of market definition. As long as the whole analysis is performed appropriately, there is no doubt that the conclusions must maintain the same according to either approach.

Consequently, this article would like to make two observations based on its survey. First, the current EU telecommunications regulation suggests that CATV networks should in principle not be subject to ex-ante broadband access obligations. Secondly, the presence of broadband over CATV is able to constrain the market power of PSTN incumbents, and thus can potentially deregulate the latter.

However, the Commission also leaves open the question with regard to the exceptional circumstances where CATV operators can be considered to effectively restrict the PSTN operators. It indeed provides several guidelines on how to reflect direct and indirect constraints when evaluating the market power of broadband over CATV. However, the standard of proof is raised so high that all the attempts from Member States have failed. This in practice makes it impossible for NRAs to have CATV network subject to open access obligations. As discussed before, even in the Hungarian case where the CATV operator has a similar weight as the PSTN operator on the retail broadband market, they are still not considered to pose effective indirect constraints. Moreover, such high standard of proof may also account for the fact that Belgium, as a country with strong presence of CATV-based broadband, never took CATV into account when reviewing Market 4 and Market 5. ${ }^{3}$ This leads to an impression that the Commission has no intention to regulate CATV networks.

Such an intention of the Commission to deregulate broadband over CATV cannot be clearer when compared with its practice related to broadband over fibre. The Commission, in many events, underlines that CATV networks cannot offer the same level of wholesale broadband access as PSTN networks because most CATV networks are fragmented. While fibre

\footnotetext{
${ }^{3}$ In June 2011 the Belgian media regulators, after reviewing the market for retail broadcasting transmission, proposed to oblige the incumbent CATV operators to provide alternative operators with a possibility to resell their broadband internet products. The very justification behind such a proposal was that bundled offers, including broadband and TV, became more and more important in Belgium. It was thus necessary for alternative operators to be able to offer broadband services in addition to TV services in order to compete with the CATV incumbents (EC, 2011b). However, the authors cast doubt on a broader application of the Belgian practice for the subsequent four reasons. First, the open-Internet-access obligation proposed by the Belgian media regulators concerned only resale, and cannot be compared with stricter access obligations imposed on Market 4 and 5 , such as Layer 2 or 3 accesses. More importantly, this means that the alternative operators will have no control over the broadband services that they will offer, not even to say having their services differentiated from those of the incumbent operators. Secondly, there is still a debate on the appropriateness of extending access obligations from broadband to TV, or vice versa, based on bundled products offered at the retail level (Stumpf, 2011). Thirdly, it is not a common feature in the EU to regulate the retail broadcasting market. In almost all Member States this retail market has been deregulated. Last but not least, in the decision the Commission pointed out that the Belgian authorities did not sufficiently justify the proportionality of the broadband internet resale obligation. It nevertheless took no action because of its lack of competence in reviewing the remedies proposed by NRAs under the old EU consultation procedure. This situation has been improved since 26th May, 2011 with the entering into effect the new EU consultation procedure. The new EU consultation procedure affords the Commission with a say in NRAs' proposed remedies (Queck, De Streel, Hou, Jost, \& Kosta, 2010). This article is of the opinion that the Commission will be more active in monitoring the remedied proposed NRAs in the future, and consequently it will be less likely to see that insufficiently justified remedies, such as those in the Belgian case, are approved by the Commission.
} 
networks are for the time being also scattered in almost all Member States, the Commission nevertheless has never used this fact as a basis to deny the inclusion of fibre into Market 4 or Market 5. Furthermore, another concern of the Commission to include CATV networks is that the switching costs are too high for DSL-based alternative operators to migrate to CATVbased services. Therefore, CATV cannot exert direct constraints on PSTN networks. Nevertheless, it goes without any doubt that a huge amount of switching costs is also needed for alternative operators to migrate to fibre-based broadband services. The Commission nevertheless never questions the inclusion of fibre into Market 4 or Market 5, though many Member States did not clarify the extent of such switching costs between PSTN and fibre in their notifications. In addition, in view of the promising bandwidth provided over fibre, the relationship between fibre and PSTN may be comparable to that between narrowband and broadband. With regard to the latter, the Commission has maintained that narrowband and broadband should be on separate markets as the substitution between the two is only unidirectional, in other words consumers seldom switch from broadband to narrowband (EC, 2003). This is also applicable to the substitution between PSTN and fibre since not many fibre consumers are expected to switch back to PSTN. Again, the Commission never raises this question when analysing whether fibre should be included into Market 4 and Market 5. Instead, what is commonly seen is that the Commission constantly accused Member States of not including fibre into their regulation.

The Commission's deregulatory intention for broadband over CATV may reflect the concern that service-based intraplatform competition may have a negative effect on broadband penetration. According to Bouckaert, van Dijk, and Verboven (2010), countries that focus on inter-platform competition have performed significantly better, and access regulation directly discourages investment.

In addition, it seems that CATV networks will not be subject to open-access obligations for their life time. The Europe 2020 Strategy expects to improve the average broadband speed for all EU citizens by 2020 about fifty times higher than the current EU average (EC, 2010b). It thus sets up a clear target to foster the deployment and take-up of next generation access networks. Under such a policy it can be foreseen that the current generation access networks, such as PSTN and CATV, will be gradually and persistently migrated to fibre and disappearing in the coming years.

\section{Acknowledgements}

The authors gratefully acknowledge the helpful comments of the attendees in the 22nd European ITS Regional Conference, Budapest, 19-21 September, 2011, as well as the remarks from the anonymous reviewers. Any error or misunderstanding can only be attributed to the authors.

\section{References}

Bánhidi, F., \& Pápai, Z. (2010). Challenges in the regulation of broadband in Hungary. In proceedings of the 21st european regional ITS conference. Copenhagen, Denmark. September 13-15. Available from 〈https://www.econstor.eu/dspace/bitstream/10419/44595/3/46_papai.pdf〉 Accessed 03.04.13.

Bouckaert, J., van Dijk, T., \& Verboven, F. (2010). Access regulation, competition, and broadband penetration: An international study. Telecommunications Policy, 34(11), 661-671.

Cable Europe (2006). Cable Europe response to the ERG consultation on WP 2007. Available from 〈http://berec.europa.eu/doc/publications/consult_wp2007/ ecca erg wp.pdf (accessed 2013, April 13)

Cable Europe (2010). EU Cable Industry Consolidation YE 2011. Available from 〈http://www.cable-europe.eu/content/uploads/2012/10/121004_FF-YE-2011-F INAL.pdf) Accessed 13.04.13.

ERG (2005). Common position on bitstream access. ERG (03) 33rev2.

European Commission (EC) (2003). Case COMP/C-1/37.451, 37.578, and 37.579. Deutsche Telekom AG. OJ L 263/9. October 14. para.77.

European Commission (EC) (2007a). Commission recommendation of 17 December, 2007 on relevant product and service markets within the electronic communications sector susceptible to ex-ante regulation in accordance with directive 2002/21/EC of the European Parliament and of the Council on a common regulatory framework for electronic communications networks and services. OJ L 344/65. December 28.

European Commission (EC) (2007b). Explanatory note accompanying document to the Commission recommendation on relevant product and service markets within the electronic communications sector susceptible to ex-ante regulation in accordance with directive 2002/21/EC of the european parliament and of the council on a common regulatory framework for electronic communications networks and services. SEC(2007) 1483 final. December.

European Commission (EC) (2008a). Case NL/2008/0826. Wholesale access to the local loop for broadband and/or voice services and Case NL/2008/0827. Wholesale broadband access. December 8.

European Commission (EC) (2008b). Case DK/2008/0862. Wholesale broadband access in Denmark, 2009 , March 9.

European Commission (EC) (2008c). Case MT/2008/0803. Wholesale broadband access in Malta. November 7.

European Commission (EC) (2008d). Case PT/2008/0850. Wholesale (physical) network infrastructure access (including shared or fully unbundled access) at a fixed location and Case PT/2008/0851. Wholesale broadband access. January 5, 2009.

European Commission (EC) (2008e). Case AT/2008/0757. Wholesale broadband access in Austria. March $26,2008$.

European Commission (EC) (2009). Case EE/2009/0942. Wholesale (physical) network infrastructure access (including shared or fully unbundled access) at a fixed location. and Case EE/2009/0943. Wholesale broadband access. July 30

European Commission (EC) (2010a). 15th Progress report on the single european electronic communications market. Part I, pp. 25. Available from 〈http://ec. europa.eu/information_society/policy/ecomm/library/communications_reports/annualreports/15th/index_en.htm $>$ Accessed 13.04.13.

European Commission (EC) (2010b). Communication from the commission to the european parliament, the council, the european economic and social committee and the committee of the regions: A digital agenda for europe. COM 245. May 19.

European Commission (EC) (2010c). Case UK/2010/1064. Wholesale local access market. and Case UK/2010/1065: Wholesale broadband access market. June 1. European Commission (EC) (2010d). Case DE/2010/1116. Wholesale broadband access in Germany. September 6.

European Commission (EC) (2011a). Case HU/2011/1190. Wholesale (physical) network infrastructure access at a fixed location in Hungary and case HU/2011/ 1191. Wholesale broadband access in Hungary. April 1.

European Commission (EC) (2011b). Case BE/2011/1229. Retail market for the delivery of broadcasting signals and access to broadcast networks. June 20.

European Commission (EC) (2012). Commission Decision of 10/08/2012 pursuant to article 7 (5) of directive 2002/21/EC (withdrawal of notified draft measures). Case CZ/2012/1322. Wholesale Broadband Access in the Czech Republic. August 10. 
European Commission (EC) (2013). All registered notifications, Commission decisions and adopted measures country by country. Available from 〈https:// circabc.europa.eu/faces/jsp/extension/wai/navigation/container.jsp $\rangle$ Accessed 13.04.13.

European Union (EU) (2009a). Directive 2002/21/EC on a common regulatory framework for electronic communications networks and services, OJ L 108/33, 24.4.2002, amended by directive 2009/140/EC amending directives 2002/21/EC on a common regulatory framework for electronic communications networks and services, 2002/19/EC on access to, and interconnection of, electronic communications networks and associated facilities, and 2002/20/EC on the authorisation of electronic communications networks and services. OJ L 337/37. December 18.

European Union (EU) (2009b). Directive 2002/19/EC on access to, and interconnection of, electronic communications networks and associated facilities. OJ L 108/ 7, 2002, April 24. Amended by directive 2009/140/EC amending directives 2002/21/EC on a common regulatory framework for electronic communications networks and services, 2002/19/EC on access to, and interconnection of, electronic communications networks and associated facilities, and 2002/20/EC on the authorisation of electronic communications networks and services. OJ L 337/37. December 18.

Hou, L. (2008). The assessment of single SMP: Lessons learned from the first round of market review. Competition and Regulation in Network Industries, 9(1), 49-75.

Hou, L. (2010). Sub-national Geographic markets within the electronic communications sector. World Competition, 33(3), 437-456.

Inderst, R., \& Valletti, T. M. (2007a). A tale of two constraints: Assessing market power in wholesale markets. European Competition Law Review, 28(2), $84-91$.

Inderst, R., \& Valletti, T. M. (2007b). Market analysis in the presence of indirect constraints and captive sales. Journal of Competition Law and Economics, 3(2), 203-231.

Jones, A., \& Sufrin, B. (2011). EU competition law: text, cases and materials (p. ?63) Oxford: Oxford University Press 63.

OECD (2005). Development in local loop unbundling. DSTI/ICCP/TISP(2002)5/FINA.

Picot, A., \& Wernick, C. (2007). The role of government in broadband access. Telecommunications Policy, 31(10-11), 660-674.

Queck, R., De Streel, A., Hou, L., Jost, J., \& Kosta, E. (2010). The EU regulatory framework applicable to electronic communications. In L. Gazaniti, \& M. O'Regan (Eds.), Telecommunications, Broadcasting and the Internet: EU Competition Law and Regulation (3rd ed.). London: Sweet \& Maxwell.

Schwarz, A. (2007). Wholesale market definition in telecommunications: The issue of wholesale broadband access. Telecommunications Policy, 31(5), 251-264.

Spulber, D. F., \& Yoo, C. S. (2008). Rethinking broadband internet access. Harvard Journal of Law and Technology, 22(1), 1-74.

Stumpf, U. (2011). Dealing with multi-play bundles: A need for ex-ante regulation?. In Bundling and multi-play: does it require a new regulatory paradigm?. Brussels, Belgium. May 30-31.

Van Gorp, A., \& Middleton, C. (2010). The impact of facilities and service-based competition on internet services provision in the canadian broadband market. Telematics and Informatics, 27(3), 217-230.

Wu, I. (2004). Canada, South Korea, Netherlands and Sweden: Regulatory implications of the convergence of telecommunications, broadcasting and internet services. Telecommunications Policy, 28(1), 79-96. 